\title{
Vehicular Air Pollution, Playgrounds, and Youth Athletic Fields
}

\author{
Kenneth W. Rundell, Renee Caviston, Amanda M. Hollenbach, \\ and Kerri Murphy \\ Human Performance Laboratory, Keith J. O'Neill Center for Healthy Families, Marywood University, \\ Scranton, Pennsylvania, USA
}

\begin{abstract}
In spite of epidemiological evidence concerning vehicular air pollution and adverse respiratory/cardiovascular health, many athletic fields and school playgrounds are adjacent to high traffic roadways and could present long-term health risks for exercising children and young adults. Particulate matter $\left(\mathrm{PM}_{1}, 0.02-1.0 \mu \mathrm{m}\right.$ diameter $)$ number counts were taken serially at four elementary school athletic/playground fields and at one university soccer field. Elementary school $\mathrm{PM}_{1}$ measurements were taken over 17 days; measurements at the university soccer field were taken over 62 days. The high-traffic-location elementary school field demonstrated higher 17-day $\left[\mathrm{PM}_{1}\right]$ than the moderate and 2 low traffic elementary school fields $(48,890 \pm 34,260$, $16,730 \pm 10,550,11,960 \pm 6680,10,030 \pm 6280$, respective mean counts; $p<.05)$. The 62-day mean $\mathrm{PM}_{1}$ values at the university soccer field ranged from 115,000 to 134,000 particles $\mathrm{cm}^{-3}$. Lowest mean values were recorded at measurement sites furthest from the highway $(\sim 34,000$ particles $\left.\mathrm{cm}^{-3}\right)$ and followed a second-order logarithmic decay $\left(R^{2}=.999\right)$ with distance away from the highway. Mean $\mathrm{NO}_{2}$ and $\mathrm{SO}_{2}$ levels were below $100 \mathrm{ppb}$, mean $\mathrm{CO}$ was $0.33 \pm 1.87 \mathrm{ppm}$, and mean $\mathrm{O}_{3}$ was $106 \pm 47 \mathrm{ppb}$. Ozone increased with rising temperature and was highest in the warmer afternoon hours $(R=.61)$. Although the consequence of daily recess play and athletic activities by school children and young athletes in high ambient $\left[P M_{1}\right]$ conditions has not yet been clearly defined, this study is a critical component to evaluating functional effects of chronic combustion-derived PM exposure on these exercising schoolchildren and young adults. Future studies should examine threshold limits and mechanistic actions of real-world particle exposure.
\end{abstract}

The link between air pollution and adverse respiratory and cardiovascular health is substantial (Dockery, 2001; Kim et al., 2004; Lin et al., 2005; McConnell et al., 2003; Peters et al., 2001; Pope et al., 1991; Romieu et al., 1996). Acute pulmonary responses to short-term particulate matter (PM) exposure (Atkinson et al., 2001; Oberdorster et al., 1995) as well as decrements in resting lung function associated with chronic PM exposure have been reported (Gauderman et al., 2004; Rundell, 2004). Likewise, increased cardiac mortality and morbidity have been related to short-term elevations in air pollution (Dockery, 2001). Most recently, abnormal vascular function after acute PM exposure has been shown in animals (Nurkiewicz et al., 2004) and humans (Brook et al., 2002).

Most studies documenting adverse health effects in relation to outdoor air pollutants have relied on measured concentrations

Received 6 January 2006; accepted 16 February 2006.

Address correspondence to Kenneth W. Rundell, PhD, Professor of Health Science, Human Performance Laboratory, Keith J. O'Neill Center for Healthy Families, Marywood University, 2300 Adams Avenue, Scranton, PA 18509, USA. E-mail:rundell@marywood.edu from central monitoring stations, metrics of proximity to roads, or traffic volume estimates. However, Kim et al. (2002) measured ultrafine particles in urban Los Angeles, CA, and found that the major source was diesel and automotive exhaust. Additionally, Li et al. (2003) found that ultrafine particles contain the largest fraction of polycyclic aromatic hydrocarbons, with the highest concentration related to traffic density (Glovsky et al., 1997).

Current investigations suggest that PM toxicity is highly influenced by number concentration and/or particle surface area (Oberdorster, 1996), while ambient particulate matter with median aerodynamic diameter less than $2.5 \mu \mathrm{m}\left(\mathrm{PM}_{2.5}\right)$ has been associated with lung damage (Gauderman et al., 2004; Kim et al., 2004; McConnell et al., 2003) and cardiovascular events (Burnett et al., 1995; Peters et al., 2001; Ware, 2000). The most common source of $\mathrm{PM}_{2.5}$ is found in combustion emissions of fossil-fueled automobiles and diesel-powered trucks, with over $90 \%$ of the particle count from diesel aerosol having an aerodynamic diameter of $<30 \mathrm{~nm}$ (Kittelson et al., 2004).

Although individuals with cardiovascular disease (Burnett et al., 1995) and type 2 diabetes (Zanobetti \& Schwartz, 2001) appear to be more sensitive to ambient particle exposure than healthy adults, the developing lung of children may be 
especially vulnerable to adverse consequences of particle inhalation (Schwartz, 2004). Children may also have higher exposure to air pollutants than adults because of high outdoor physical activity and the resultant increase in minute ventilation. Exercise in high ambient particle conditions may increase risk of lung and vascular damage, since total particle deposition increases in proportion to minute ventilation and deposition fraction nearly doubles from rest to intense exercise (Daigle et al., 2003; Chalupa et al., 2004).

The purpose of this study was to document daily PM number concentrations in recreation and athletic field areas proximal to high automobile and truck traffic. This descriptive study is a first step in characterizing the potential health risk to children and young adults participating in organized and unorganized physical activities in high ambient air pollution.

\section{METHODS}

\section{Study Design}

Number counts of particles in the size range of $0.02-1.0 \mu \mathrm{m}$ aerodynamic diameter $\left(\mathrm{PM}_{1}\right)$ were taken serially at 4 elementary school athletic/playground fields and at 1 university soccer field. Nitrogen dioxide $\left(\mathrm{NO}_{2}\right)$, carbon monoxide $(\mathrm{CO})$, and ozone $\left(\mathrm{O}_{3}\right)$ were measured at the university soccer field. $\mathrm{PM}_{1}$ measurements at elementary school sites were taken over 17 days in spring 2005; measurements at the university soccer field were taken over 62 days through spring and summer 2005. $\mathrm{PM}_{1}$ measurements were taken at early to mid morning during weekdays. Figure 1A depicts the proximity of elementary schools to traffic corridors. Four elementary schools were situated near high-traffic (school 1), moderate-high-traffic (school 2), and low-traffic areas (schools 3 and 4). School 1 was directly adjacent to and east of a major route and approximately $100 \mathrm{~m}$ west of a major highway; both roads were characterized by high diesel-fueled truck traffic. School 2 was adjacent to a major village road with moderate truck and automobile traffic. Schools 3 and 4 were located in rural areas characterized by low truck and automobile traffic. All four schools were in the same school district. The university soccer field was situated such that the northeastern sideline was as close as $20 \mathrm{~m}$ from a major interstate highway characterized by heavy truck traffic (Figure 1B). Daily air quality measurements were taken at 12 sites spaced across the university soccer field.

\section{Air Quality Measurements}

Particulate matter $\left(\mathrm{PM}_{1}\right)$ was determined at each study site as previously done (Rundell, 2003). Measurements were made at $1.5 \mathrm{~m}$ height using a calibrated condensation particle counter (CPC, P-Trak ultrafine particle counter, model 8525,TSI, Inc., St. Paul MN) at a sampling frequency of $1 \mathrm{~Hz}$ and recorded as 10-s means of $\mathrm{PM}_{1} \mathrm{~cm}^{-3}$. Four 10-s readings were taken for each measurement and averaged to provide the most representative particle count for a specific measurement site. Particle counts at elementary schools and the 62-day university soccer field

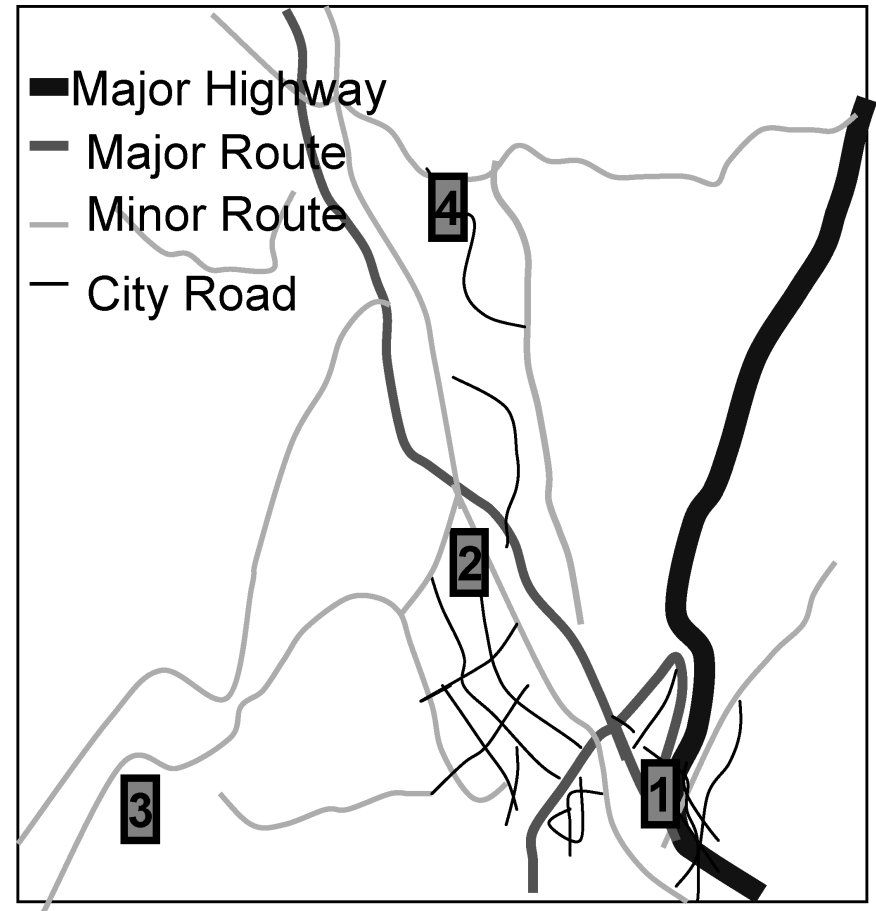

(A)

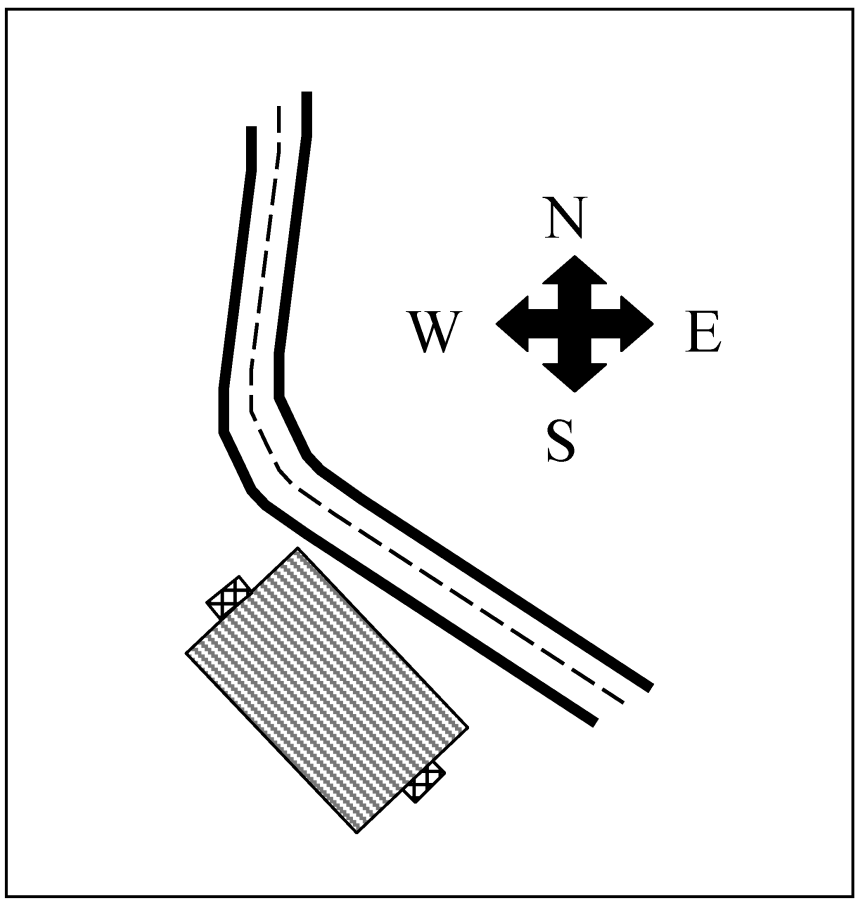

(B)

FIG. 1. (A) Location proximity of four elementary schools to automobile and truck traffic roadways. School 1 is located between a major interstate highway and a heavily traveled state route, school 2 is located proximal to a moderately traveled main road, and schools 3 and 4 are located in rural low traffic settings. (B) Relative location of the university soccer field in relation to a heavily traveled major interstate highway. 
particle counts were done at early/mid morning. The P-Trak $\mathrm{CPC}$ sensitivity size range is $0.02-1.0 \mu \mathrm{m}$ diameter; this range includes ultrafine and fine $\mathrm{PM}$, defined as $\mathrm{PM}_{1}$ in this study. $\mathrm{PM}_{1}$ has been shown to account for $>90 \%$ of total particle count and $>95 \%$ of particle surface area $\left(\mu \mathrm{m}^{2} / \mathrm{cm}^{3}\right)$ for unit density mass concentration of combustion derived air samples (Oberdorster et al., 1992, 1995). Two hundred and twenty-five measurements of $\mathrm{NO}_{2}, \mathrm{CO}$, and $\mathrm{O}_{3}$, and temperature (as 10-s mean values) with corresponding $\mathrm{PM}_{1}$ counts and temperatures were taken at the university soccer field during early morning to midafternoon hours (GrayWolf Direct Sense TOX, Trumbull CT).

\section{Statistical Analysis}

Mean values for all measured variables were calculated. Correlations between variables were determined using Pearson product moment correlations. Analysis of variance was used to determine significant differences between elementary school $\mathrm{PM}_{1}$ counts. Nonlinear regression analysis was used to determine $\mathrm{PM}_{1}$ decay across the university soccer field from close to far proximity to the major highway. A value of $p<.05$ was considered significant.

\section{RESULTS}

High-traffic school 1 demonstrated an approximate four-fold greater 17-day mean $\left[\mathrm{PM}_{1}\right]$ than moderate-traffic school 2 and low-traffic rural schools 3 and $4(p<.05)$, while moderatetraffic school 2 had a significantly greater 17 -day mean $\left[\mathrm{PM}_{1}\right]$ than low-traffic school $4(48,890 \pm 34,260,16,730 \pm 10,550$, $11,960 \pm 6680,10,030 \pm 6280$, respective mean counts; Figure $2 \mathrm{~A}, p<.05)$. Figure $2 \mathrm{~B}$ depicts high and low $\left[\mathrm{PM}_{1}\right]$ for all four school athletic fields; the high $\left[\mathrm{PM}_{1}\right]$ measurement for school 1 was 5.3-, 9.1-, and 8.4-fold higher than that measured at schools 2,3, and 4, respectively.

Figure 3A depicts $\left[\mathrm{PM}_{1}\right]$ at 12 different measurement locations on the university soccer field. Particle concentrations were highest at the 4 measurement sites closest to the highway with mean $\mathrm{PM}_{1}$ values ranging between 115,000 and 134,000 particles $\cdot \mathrm{cm}^{-3}$. The lowest mean values were recorded at the measurement sites furthest from the highway with $\mathrm{PM}_{1}$ values of $\sim 34,000$ particles $\cdot \mathrm{cm}^{-3}$. Soccer field particle concentrations followed a second order logarithmic decay $\left(R^{2}=.999\right)$ with distance away from the highway (Figure 3B).

Figure $4 \mathrm{~A}$ presents daily particle counts as mean values of the 12 measurement sites) for the university soccer field; Figure 4B depicts the number of days for categorized particle counts. No significant difference between the number of days in each particle count category was found; however, 18 (29\%) of the 62 days had mean particle counts over 100,000 particles $\mathrm{cm}^{-3}$ and almost half ( 30 days) of the 62 days ( $48 \%$ ) had mean counts over 60,000 particles $\mathrm{cm}^{-3}$. Only 11 days $(18 \%)$ had mean counts below 20,000 particles $\mathrm{cm}^{-3}$; this was significantly less than the number of days above 20,000 particles $\mathrm{cm}^{-3}(p<.05)$.

Wind direction was a critical variable in particle count values. Mean particle counts over 100,000 particles $\cdot \mathrm{cm}^{-3}$ were
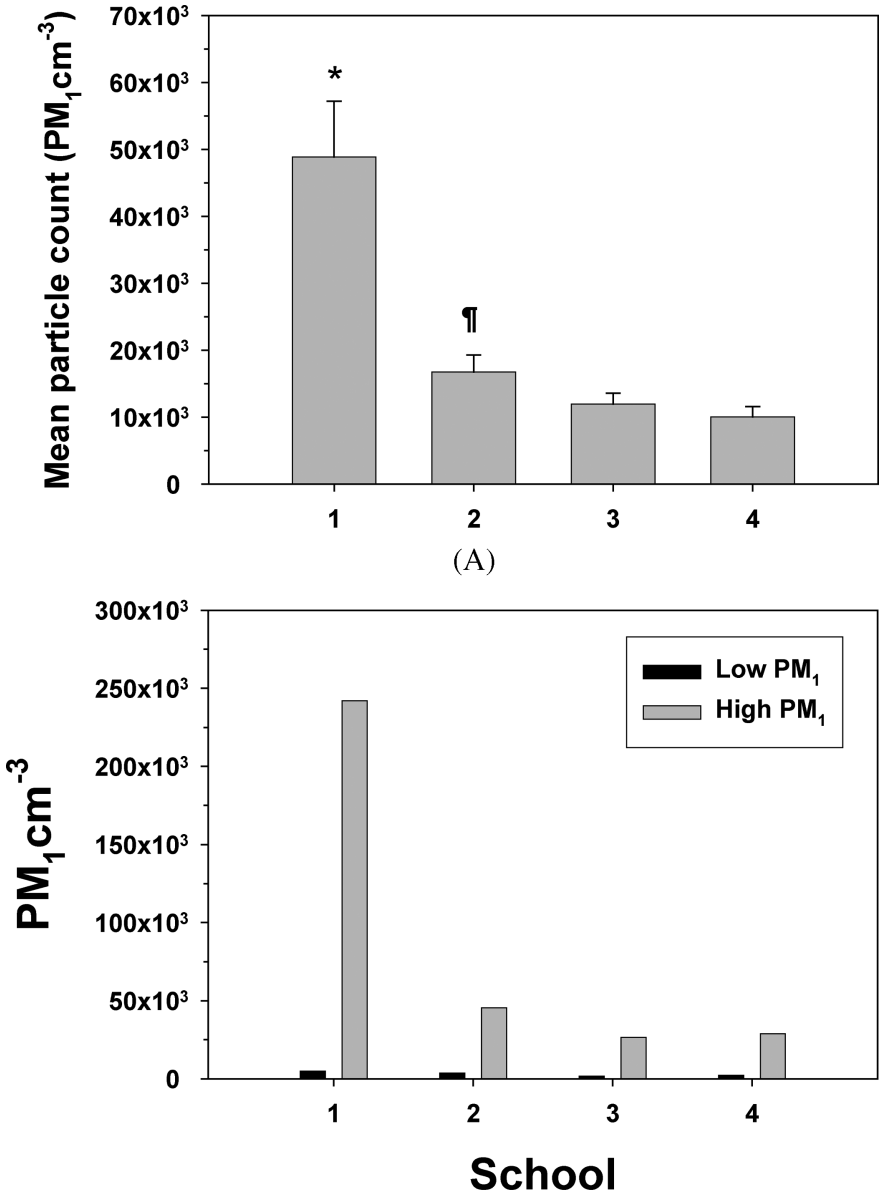

(B)

FIG. 2. (A) Elementary school playground 1 (asterisk) demonstrates significantly $(p<.05)$ higher 17 -day mean $\left[\mathrm{PM}_{1}\right]$ than elementary school playgrounds 2,3 , and 4 ; elementary school playground 2 had significantly higher 17-day mean $\left[\mathrm{PM}_{1}\right]$ than elementary school playground 4 ( $\Phi$ indicates, $p<.05$ ). Values are presented as mean $\pm \mathrm{SE}$ ). (B) Daily high and low $\left[\mathrm{PM}_{1}\right]$ values.

recorded when the wind direction was from the north and east $(101,610 \pm 50,370)$ or calm $(103,070 \pm 28,590)$. Lowest mean particle counts were recorded when wind direction was from the south and west $(45,590 \pm 37,850)$ and variable $(59790 \pm$ 55,300) (Figure 5).

Mean $\mathrm{NO}_{2}$, and $\mathrm{SO}_{2}$ levels were below $100 \mathrm{ppb}$, mean $\mathrm{CO}$ was $0.33 \pm 1.87 \mathrm{ppm}$, and mean $\mathrm{O}_{3}$ was $106 \pm 47 \mathrm{ppb}$. Ozone increased with rising temperature and was highest in the warmer afternoon hours $\left(R=.61\right.$, Figure 6A). When $\mathrm{O}_{3}$ levels were grouped according to $5^{\circ} \mathrm{C}$ temperature increments from 18 to $33^{\circ} \mathrm{C}$, the highest temperature group was significantly different than the lower two temperature groups; the middle temperature group was significantly higher than the lower temperature group (Figure 6B). 


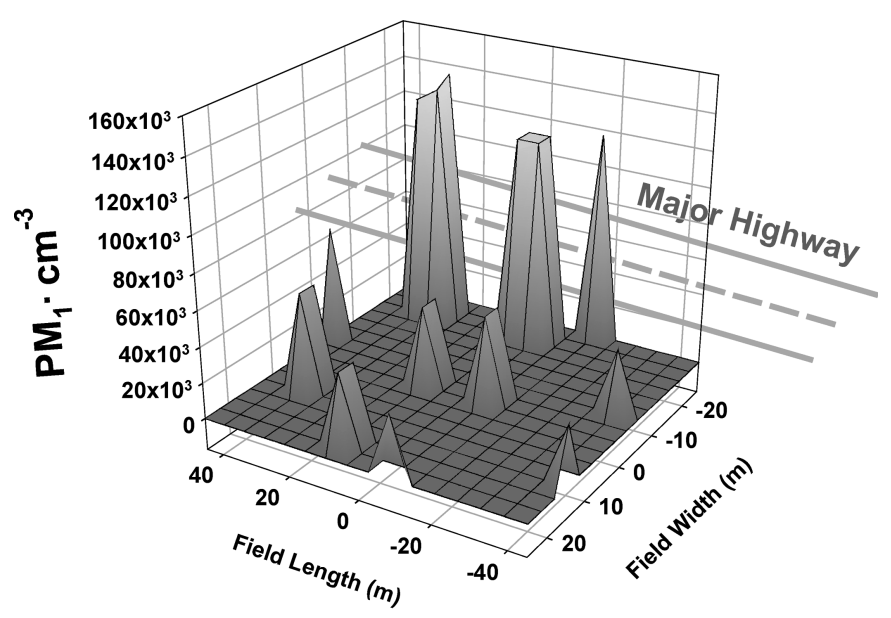

(A)

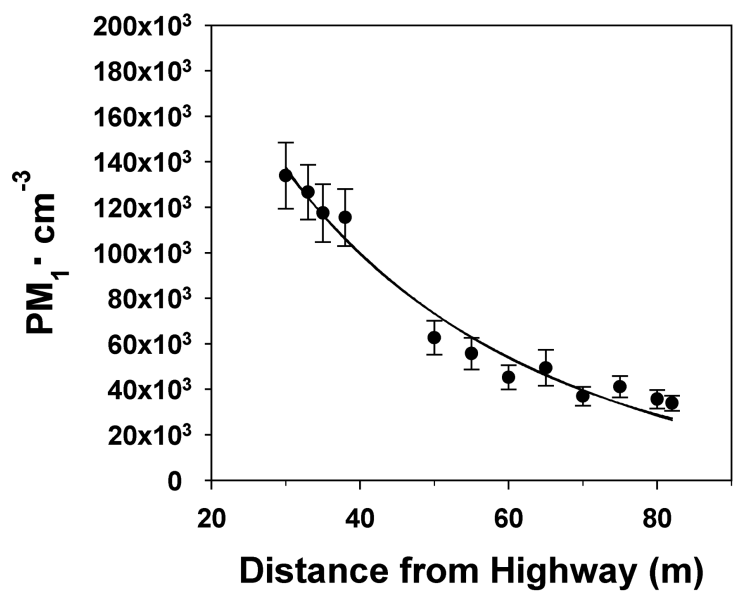

(B)

FIG. 3. (A) Three dimensional depiction of 62-day $\left[\mathrm{PM}_{1}\right]$ mean measurements taken at 12 different locations at a university soccer field located next to a major interstate highway. (B) Rate of $\left[\mathrm{PM}_{1}\right]$ decay (using 62-day mean values at soccer field measurement sites) in relation to distance from the interstate $(R=-.999$; values are presented as mean $\pm \mathrm{SE})$.

\section{DISCUSSION}

This study demonstrated strong relationships between ambient $\left[\mathrm{PM}_{1}\right]$ and distance from high traffic roads. We documented higher mean ambient $\left[\mathrm{PM}_{1}\right]$ at elementary school playground/athletic fields adjacent to high-traffic roads than those in low traffic rural settings. The measured $\left[\mathrm{PM}_{1}\right]$ levels at the high traffic study sites were severalfold higher than $\left[\mathrm{PM}_{1}\right]$ levels measured in rural areas. Likewise, we documented a mean 62-day $\mathrm{PM}_{1}$ count of 71,000 $\pm 51,000$ particles $\mathrm{cm}^{-3}$ (range: 6500-203,000) for a near-highway university soccer field; mean values were obtained from 3 averaged $10-\mathrm{s}\left[\mathrm{PM}_{1}\right]$ recordings at 12 locations distributed across the field. Almost 50\% of 62 count-days at the university soccer field had 12 -site mean $\mathrm{PM}_{1}$ counts over 60,000 particles $\mathrm{cm}^{-3}$ and $29 \%$ of the measurement days had mean counts greater than 100,000 particles $\mathrm{cm}^{-3}$.
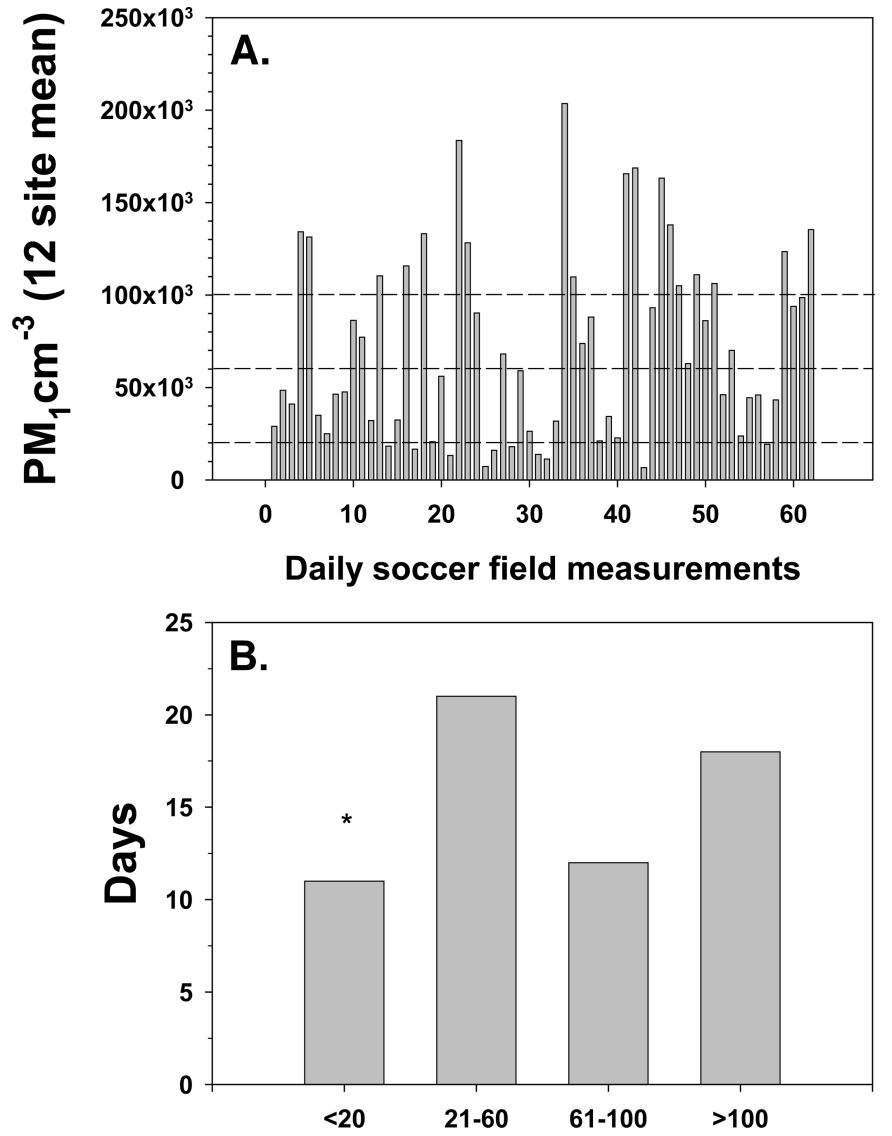

FIG. 4. (A) Daily mean $\left[\mathrm{PM}_{1}\right]$ values of 12 measurement sites on the university soccer field. (B) Number of days with mean $\mathrm{PM}_{1}$ counts below 20,000 particles $\mathrm{cm}^{-3}$ was significantly less than days $>20,000000$ particles $\cdot \mathrm{cm}^{-3}$.

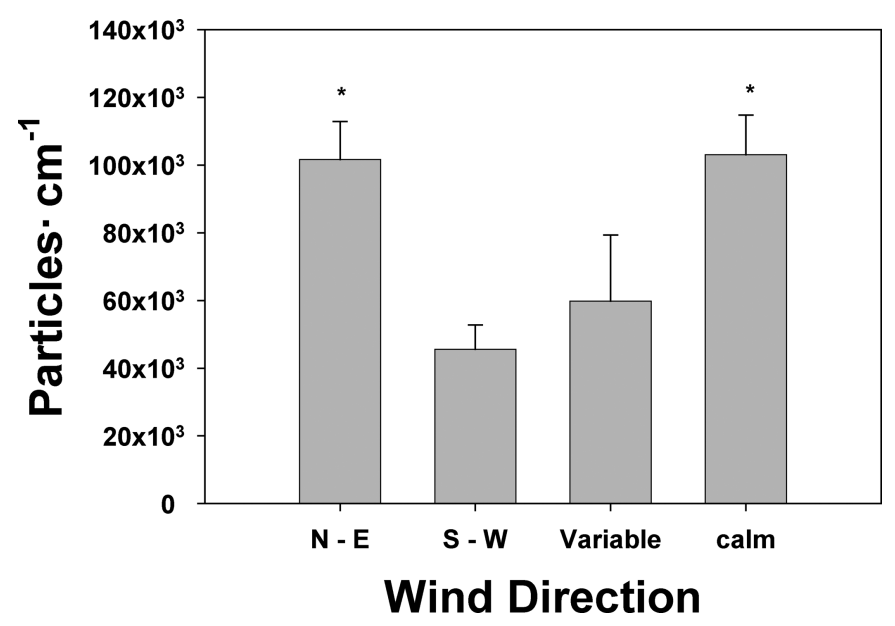

FIG. 5. Particle counts were categorized according to wind direction; northeast wind and calm winds demonstrated significantly higher $\left[\mathrm{PM}_{1}\right]$ than southwest winds. Refer to map in Figure 1 (A). Asterisk indicates significantly different than from southwest (S-W), $p<.05$. 


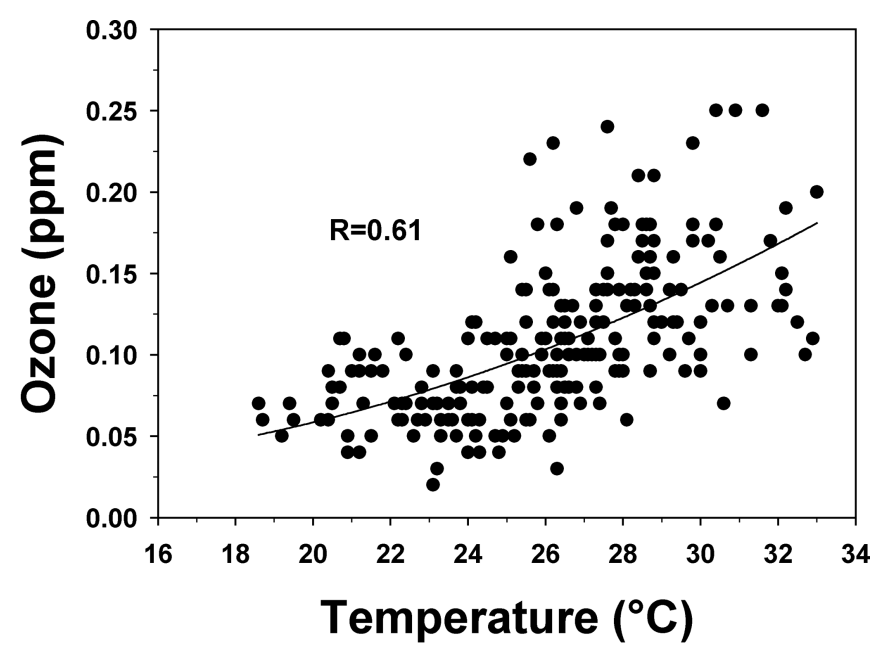

(a)

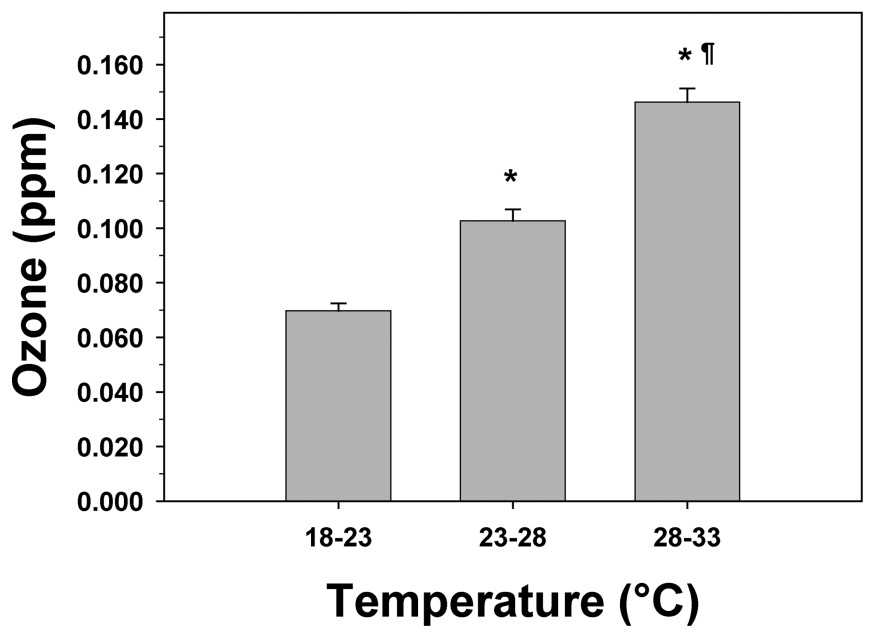

(b)

FIG. 6. (A) Significant positive relationship between $\mathrm{O}_{3}$ and temperature, with more than half of the $\mathrm{O}_{3}$ measurements greater than 100 ppb. (B) $\mathrm{O}_{3}$ levels (ppb) grouped according to $5^{\circ} \mathrm{C}$ temperature categories. Asterisk indicates significantly greater $\left[\mathrm{O}_{3}\right]$ than $18-23^{\circ} \mathrm{C}$ group, $p<.05$; 9 indicates significantly greater $\left[\mathrm{O}_{3}\right]$ than $18-23^{\circ} \mathrm{C}$ and $23-28^{\circ} \mathrm{C}$ groups, $p<.05$.

A second-order logarithmic decline in $\left[\mathrm{PM}_{1}\right](R=-.99)$ showed that particle number counts at $80 \mathrm{~m}$ from a major highway were $\sim 3$-fold lower than number counts $30 \mathrm{~m}$ from the highway. Particle counts were highly dependent on wind direction in relation to the high-traffic particle source and measurement sites; highest particle counts were measured when the wind direction was from the highway or on days with no measurable wind. This finding was consistent with the exponential decay of ultrafine particles with distance away from a major CA freeway (Zhu et al., 2002).

Of particular importance to the present study is the potential effect of ambient air pollution on exercising children and college athletes. Reduced lung development in children exposed to high levels of ambient air pollution has been found (Gauderman et al., 2004). We have previously shown a significant decline in $\mathrm{FEV}_{1}$ in women ice hockey players after $3 \mathrm{yr}$ of training in an ice rink with high ice resurfacer emission $\left[\mathrm{PM}_{1}\right]$; the largest decrease in lung function occurred after only 3 mo of daily exposure (Rundell, 2004). Kim et al. (2004) found strong correlations between black carbon concentrations and bronchitis $(R=.76)$ and asthma prevalence $(R=.83)$ in a school-based cross-sectional study using a parental questionnaire. Another study (McConnell et al., 2003) lasting over a 3-yr period identified yearly variability of ambient organic carbon as having the strongest association to bronchial symptoms (odds ratio $1.41 / \mu \mathrm{g} / \mathrm{m}^{3} ; 95 \%$ confidence interval 1.12-1.78). Particulate air pollution has been associated with hospital admissions for asthma (Atkinson et al., 2001; Pope et al., 1991) and decline in peak expiratory flow rates (Romieu et al., 1996). Recently, Lin et al. (2005) identified a relationship between relatively low levels of ambient particulate matter on hospitalization for respiratory infections in children, with the strongest associations to coarse particulate matter.

Total respiratory number deposition fraction during exercise has been found to increase approximately $32 \%$ over resting values and to exceed predicted values for exercise by approximately $22 \%$ for 26-nm particles (Daigle et al., 2003). Prediction models of particle deposition indicate that particles in the $30-\mathrm{nm}$ size range are predominately deposited in airway generations 19-22 during exercise. Considering that greater than $90 \%$ of auto and truck emission particle number is found in the 3-30 $\mathrm{nm}$ size range and most of the particle mass is found in the 30 $500 \mathrm{~nm}$ size range, particle deposition in the alveolar region is most likely high for individuals exercising in high auto emission conditions (ICRP, 1994).

Increased oxidative stress from $\mathrm{PM}_{1}$ inhalation is likely, as the formation of reactive oxygen species (ROS) has been associated with PM exposure and has been shown to influence mediator release (Ware, 2000; Werz et al., 2000). Li et al. (2003) found that ultrafine particles $\left(\mathrm{PM}_{0.1}\right)$ were more potent than coarse $\left(\mathrm{PM}_{10}\right)$ or fine $\left(\mathrm{PM}_{2.5}\right)$ particles toward generation of ROS and in depleting intracellular glutathione in lung macrophage and epithelial cells in vitro. Voelkel et al. (2003) demonstrated that ROS and exhaled nitric oxide (eNO) increased from $\mathrm{PM}_{0.1}$ exposure. It is likely that PM-initiated ROS increases lipid peroxidation and leukotriene production, since recent reports support 5-lipoxygenase activation by ROS, and contributes to a three- to fourfold increase in leukotriene synthesis in vitro (Werz et al., 2000; Woo et al., 2000).

Additionally, measured ozone levels were positively related to temperature $(R=.61)$ with a mean value of $106 \pm 47 \mathrm{ppb}$ for 221 measurements. Late-afternoon ozone levels at a temperature range of $28-33^{\circ} \mathrm{C}(146 \pm 44 \mathrm{ppb} ; 63$ measurements) exceeded Nation Ambient Air Quality Standards for Criteria Air Pollutants of 120 ppb $\mathrm{O}_{3}$ for 1-h average, and were significantly higher than morning and early-afternoon measurements at lower temperatures (cf. Figure 6). Ozone is a strong oxidant and has been shown to cause airway inflammation, abnormal 
lung function, and respiratory symptoms at levels below those identified in the present study. Ambient ozone is formed from the photochemical reaction of nitrogen oxides found in traffic related pollutants and tends to be highest in the late afternoon. Several studies have shown a causal relationship between $\mathrm{O}_{3}$ exposure and respiratory-tract symptoms, decreased lung function, and asthma exacerbations (Gent et al., 2003; Kinney et al., 1996). Exposure to $\mathrm{O}_{3}$ levels below $60 \mathrm{ppb}$ has been shown to affect lung function in amateur cyclists, and it has been speculated that childhood exposure may have detrimental effects on lung function later in life (Galizia \& Kinney, 1999).

Although the current study is descriptive in nature, numerous epidemiological studies have identified robust relationships between ambient particle exposure and respiratory conditions. The consequence of daily recess play and athletic activities by school children and young athletes in high ambient $\left[\mathrm{PM}_{1}\right]$ conditions has not yet been clearly defined. This study is a critical component in evaluating functional effects of chronic exposure to internal combustion derived particulate matter on exercising school children and young adults. Future studies should examine threshold limits and mechanistic actions of real-world particle exposure.

\section{REFERENCES}

Atkinson, R. W., Anderson, H. R., Sunyer, J., Ayres, J., Baccini, M., Vonk, J. M., Boumghar, A., Forastiere, F., Forsberg, B., Touloumi, G., Schwartz, J., and Katsouyanni, K. 2001. Acute effects of particulate air pollution on respiratory admissions: results from APHEA 2 project. Air Pollution and Health: A European Approach. Am. J. Respir. Crit. Care Med. 164(10 Pt 1):18601866.

Brook, R. D., Brook, J. R., Urch, B., Vincent, R., Rajagopalan, S., and Silverman, F. 2002. Inhalation of fine particulate air pollution and ozone causes acute arterial vasoconstriction in healthy adults. Circulation 105:1534-1536.

Burnett, R. T., Dales, R. E., Krewski, D., Vincent, R., Dann, T., and Brook, J. R. 1995. Associations between ambient particulate sulfate and admissions to Ontario hospitals for cardiac and respiratory diseases. Am. J. Epidemiol. 142:15-22.

Chalupa, D. C., Morrow, P. E., Oberdorster, G., Utell, M. J., and Frampton, M. W. 2004. Ultrafine particle deposition in subjects with asthma. Environ. Health Perspect. 112(8):879-882.

Daigle, C. C., Chalupa, D. C., Gibb, F. R., Morrow, P. E., Oberdorster, G., Utell, M. J., and Frampton, M. W. 2003. Ultrafine particle deposition in humans during rest and exercise. Inhal. Toxicol. 15(6):539552.

Dockery, D. W. 2001. Epidemiologic evidence of cardiovascular effects of particulate air pollution. Environ. Health Perspect. 109(suppl. 4):483-486.

Galizia, A., and Kinney, P. L. 1999. Long-term residence in areas of high ozone: associations with respiratory health in a nationwide sample of nonsmoking young adults. Environ. Health Perspect. 107(8):675679.

Gauderman, W. J., Avol, E., Gilliland, F., Vora, H., Thomas, D., Berhane, K., McConnell, R., Kuenzli, N., Lurmann, F., Rappaport, E., Margolis, H., Bates, D., and Peters, J. 2004. The effect of air pollution on lung development from 10 to 18 years of age. N. Engl. J. Med. 351(11):1057-1067.

Gent, J. F., Triche, E. W., Holford, T. R., Belanger, K., Bracken, M. B., Beckett, W. S., and Leaderer, B. P. 2003. Association of low-level ozone and fine particles with respiratory symptoms in children with asthma. J. Am. Med. Assoc. 290(14):1859-1867.

Glovsky, M. M., Miguel, A. G., and Cass, G. R. 1997. Particulate air pollution: Possible relevance in asthma. Allergy Asthma Proc.18:163166.

International Committee on Radiological Protection. 1994. Human respiratory tract model for radiological protection. A report of Committee 2 of the ICRP. Oxford: Pergamon Press.

Kim, J. J., Smorodinsky, S., Lipsett, M., Singer, B. C., Hodgson, A. T., and Ostro, B. 2004. Traffic-related air pollution near busy roads: The East Bay Children's Respiratory Health Study. Am. J. Respir. Crit. Care Med. 170(5):520-526.

Kim, S., Shen, S., and Sioutas, C. 2002. Size distribution and diurnal and seasonal trends of ultrafine particles in source and receptor sites of the Los Angeles basin. J. Air Waste Manage. Assoc. 52:297307.

Kinney, P. L., Thurston, G. D., and Raizenne, M. 1996. The effects of ambient ozone on lung function in children: A reanalysis of six summer camp studies. Environ. Health Perspect. 104(2):170174.

Kittelson, D. B., Watts, W. F., Johnson, J. P., Remerowki, M. L., Ische, E. E., Oberdorster, G., Gelein, R. M., Elder, A., Hopke, P. K., Kim, E., Zhao, W., Zhou, L., and Jeong, C. H. 2004. On-road exposure to highway aerosols. 1. Aerosol and gas measurements. Inhal. Toxicol. 16(suppl. 1):31-39.

Li, N, Sioutas, C., Froines, J. R., Cho, A., Misra C., and Nel, A. 2003. Ultrafine particulate pollutants induce oxidative stress and mitochondrial damage. Environ. Health Perspect. 111(4):455460.

Lin, S., Kielb, C., Chen, Z., and Hwang, S. A. 2005. Childhood asthma hospitalization rates, childhood asthma prevalence, and their relationships in Erie County, New York. J. Asthma 42(8):653658.

McConnell, R., Berhane, K., Gilliland, F., Molitor, J., Thomas, D., Lurmann, F., Avol, E., Gauderman, W. J., and Peters, J. M. 2003. Prospective study of air pollution and bronchitic symptoms in children with asthma. Am. J. Respir. Crit. Care Med. 168(7):790797.

Nurkiewicz, T. R., Porter, D. W., Barger, M., Castranova, V., and Boegehold, M. A. 2004. Particulate matter exposure impairs systemic microvascular endothelium-dependent dilation. Environ. Health Perspect. 112:1299-1306.

Oberdorster, G. 1996. Significance of particle parameters in the evaluation of exposure-dose-response relationships of inhaled particles. Inhal. Toxicol. 8(suppl.):73-89.

Oberdorster, G., Ferin, J., Gelein, R., Soderholm, S. C., and Finkelstein, J. 1992. Role of the alveolar macrophage in lung injury: Studies with ultrafine particles. Environ. Health Perspect. 97:193199.

Oberdorster, G., Gelein, R. M., Ferin, J., and Weiss, B. 1995. Association of particulate air pollution and acute mortality: Involvement of ultrafine particles? Inhal. Toxicol. 7(1):111-124.

Peters, A., Frohlich, M., Doring, A., Immervoll, T., Wichmann, H. E., Hutchinson, W. L., Pepys, M. B., and Koenig, W. 2001. Particulate air pollution is associated with an acute phase response in men; Results 
from the MONICA-Augsburg Study. Eur. Heart J. 22(14):11981204.

Pope, C. A. 3rd, Burnett, R. T., Thurston, G. D., Thun, M. J., Calle, E. E., Krewski, D., Godleski, J. J. 2004. Cardiovascular mortality and long-term exposure to particulate air pollution: epidemiological evidence of general pathophysiological pathways of disease. Circulation. 109(1):71-77.

Romieu, I., Meneses, F., Ruiz, S., Sienra, J. J., Huerta, J., White, M. C., and Etzel, R. A. 1996. Effects of air pollution on the respiratory health of asthmatic children living in Mexico City. Am. J. Respir. Crit. Care Med. 154:300-307.

Rundell, K. W. 2003. High levels of airborne ultrafine and fine particulate matter in indoor ice arenas. Inhal. Toxicol. 15(3):237-250.

Rundell, K. W. 2004. Pulmonary function decay in women ice hockey players: Is there a relationship to ice rink air quality? Inhal. Toxicol.16(3):117-123.

Rundell, K. W., Spiering, B. A., Baumann, J. M., and Evans, T. M. 2005. Bronchoconstriction provoked by exercise in a high-particulatematter environment is attenuated by montelukast. Inhal. Toxicol. 17(2):99-105.

Schwartz, J. 2004. Air pollution and children's health. Pediatrics 113:1037-1043.
Schwartz, J., and Morris, R. 1995. Air pollution and hospital admissions for cardiovascular disease in Detroit, Michigan. Am. J. Epidemiol. 142(1):23-35.

Voelkel, K., Krug, H. F., and Diabate, S. 2003. Formation of reactive oxygen species in rat epithelial cells upon stimulation with fly ash. J. Biosci. 28(1):51-55.

Ware, J. H. 2000. Particulate air pollution and mortality-clearing the air. N. Engl. J. Med. 348:1798-1799.

Werz, O., Szellas, D., and Steinhilber, D. 2000. Reactive oxygen species released from granulocytes stimulate 5-lipoxygenase activity in a Blymphocytic cell line. Eur. J. Biochem. 267(5):1263-1209.

Woo, C. H., Lee, Z. W., Kim, B. C., Ha, K. S., and Kim, J. H. 2000. Involvement of cytosolic phospholipase A2, and the subsequent release of arachidonic acid, in signalling by rac for the generation of intracellular reactive oxygen species in rat-2 fibroblasts. Biochem. $J$. 348:525-530.

Zanobetti, A., and Schwartz, J. 2001. Are diabetics more susceptible to the health effects of airborne particles? Am. J. Respir. Crit. Care Med. 164(5):831-833.

Zhu, Y., Hinds, W. C., Seongheon, K., and Sioutas, C. 2002. Concentration and size distribution of ultrafine particles near a major highway. Air Waste Manage. Assoc. 52:1032-1042. 